\title{
ФАКТОРЫ, ВЛИЯЮЩИЕ НА ЧИСЛЕННОСТЬ СОРНЫХ РАСТЕНИЙ В ПОСЕВАХ ЯРОВОЙ ПШЕНИЦЫ, НА ПРИМЕРЕ ЛЕСОСТЕПИ ЗАПАДНОЙ СИБИРИ
}

\author{
V.E. Sineshchekov, N.V. Vasilyeva
}

\section{THE FACTORS INFLUENCING THE NUMBER OF WEED PLANTS IN THE CROPS OF SPRING WHEAT ON THE EXAMPLE OF FOREST STEPPE OF WESTERN SIBERIA}

Синещеков Виктор Ефимович - д-р с.-х. наук, гл. науч. сотр, зав. лаб. агротехнологий Сибирского НИИ земледелия и химизации сельского хозяйства СФ НЦА РАН, Новосибирская обл., Новосибирский р-н, р.п. Краснообск.

E-mail: sivi_01@mail.ru

Васильева Надежда Викторовна - канд. биол. наук, ст. науч. сотр. лаб. агротехнологий Сибирского НИИ земледелия и химизации сельского хозяйства СФ НЦА РАН, Новосибирская обл., Новосибирский р-н, р.п. Краснообск. E-mail: sivi_01@mail.ru

Задачи исследований - определение фракторов, влияющих на изменение численности и видового состава сорных растений, и поиск способов эфрфрективного сдерживания численности сорных растений в посевах яровой пшеницы при разных приемах минимизации обработки почвы. Исследования проводили в полевом стационарном опыте СИбНИИЗиХ СФ НЦА РАН в лесостепи Западной Сибири на протяжении 34 лет. С 1981 по 1990 е. культуры воздельвали в 5-польном севообороте: пар-озимая рожьпшеница-овес (ячмень)-пшеница; в 19912006 г2. его реорганизовали в 4-поль-ный: парозимая рожь-пшеница-пшеница; с 2007 г. озимую рожь заменили пшеницей: пар-пшеницапшеница-пшеница. В зернопаровом севообороте исследовали разные варианты зяблевой обработки почвы: 1. Вспашка на 20-22 см (в пару на 25-27 см). 2. Безотвальная обработка стойками СибИМЭ на 20-22 см (в пару на 25-27 см). 3. Минимальная обработка культиватором «Степняк» на глубину 10-12 см.4. Без зяблевой обработки («нулевая обработка»). Размер опытных вариантов составлял 1300 м². Сравнивали также два фона химизации - контроль-
Sineshchekov Victor Efimovich - Dr. Agr. Sci., Chief Staff Scientist, Head, Lab. of Agrotechnologies, Siberian Research and Development Institute of Agriculture and Chemicalixation of Agriculture SF RCA RAS, Novosibirsk Region, Novosibirsk district, W.S. Krasnoobsk. E-mail: sivi_01@mail.ru Vasilyeva Nadezhda Victorovna - Cand. Biol. Sci., Senior Staff Scientist, Lab. of Agrotechnologies, Siberian Research and Development Institute of Agriculture and Chemicalixation of Agriculture SF RCA RAS, Novosibirsk Region, Novosibirsk district,W.S. Krasnoobsk.E-mail: sivi_01@mail.ru

ный и интенсивный. На контрольном фоне не применяли средства химизации. На интенсивном фоне применяли удобрения, гербициды, фунгициды и инсектициды. Исследования показали, что без средств химической защиты растений в полях зернопарового севооборота идет постепенное накопление сорной растительности. Нарастание численности сорняков происходило значительно быстрее в вариантах минимальной зяблевой обработки почвы и без зяби («нулевая» обработка), чем в варианте «вспашка». Минимизация обработки почвы без применения гербицидов приводила к увеличению засоренности посевов в 1,4-1,8 раза. Отказ от зяблевой обработки почвы вызвал увеличение числа сорных растений в 2,3 раза в сравнении со вспашкой. Засоренность посевов существенно зависела от индекса увлажнения года. В засушливые годы (коэффрициент увлажнения < 0,8) засоренность поля за 20 лет составила 8,9 \%, а во влажные годы (коэфрфициент увлажнения > 1,2) - 28,0 \%. Отмечено также появление в лесостепи степных видов сорных растений на поле, что, возможно, связано с потеплением климата в Западной Сибири. На 
интенсивном фоне для снижения засоренности применяли баковую смесь гербицидов один раз за вегетацию. Это приводило к минимуму численности сорных растений на протяжении всего периода наблюдений во всех вариантах обработки почвы.

Ключевые слова: сорные растения, гербициды, яровая пшеница, минимальные обработки почвы, севооборот.

The objectives of the research were to determine the factors affecting the change in the number and species composition of weeds and the search for the ways of effective control of the number of weeds in spring wheat crops with different methods of minimizing soil cultivation. The researches were held in the stationary field experiment "SibRIACA" SF RCA RAS in the forest steppe of Western Siberia for 34 years. From 1981 to 1990 the crops were cultivated in a 5-field crop rotation: fallow-winter rye-wheat-oats (barley) -wheat; in 1991-2006 it was reorganized into 4-field: fallow -winter ryewheat-wheat; since 2007, winter rye has been replaced by wheat: fallow-wheat-wheat-wheatwheat. In grain-crop rotation, different options for autumn tillage were studied: 1. Plowing, 20-22 cm (in fallow 25-27 cm). 2. Slot-free processing with SibIME racks of 20-22 cm (in fallow of 25-27 cm). 3. The minimum cultivation with cultivator "Stepnyak" to the depth of 10-12 cm. 4. Without chamfering ("zero chipping"). The size of experimental options was $1300 \mathrm{~m}^{2}$. Two chemicalization backgrounds were also compared, i.e. control and intensive. On the control background no chemicals were used. Fertilizers, herbicides, fungicides and insecticides were used against intensive background. The studies showed that without means of chemical plant protection in the fields of grain-crop rotation there had been gradual accumulation of weed vegetation. The increase in the number of weeds occurred much faster in the variants of minimum chaffing tillage and without chilling ("zero" cultivation) than in "plowing" variant. Minimization of soil cultivation without using herbicides led to the increase in crops weediness of by 1.4-1.8 times. Refusal from autumn tillage caused a 2.3-fold increase in the number of weeds compared to plowing. Weed infestation depended significantly on humidification index of the year. In dry years (moistening coefficient $<0.8$ ), the weediness of the field over the course of 20 years was $8.9 \%$, and in wet years (moistening coefficient> 1.2) it made $28.0 \%$. The appearance in the forest-steppe of steppe species of weed plants on the field was also noted, which was possibly associated with climate warming in Western Siberia. Against intensive background, tank mixture of herbicides was used once per vegetation to reduce clogging. It minimized the number of weeds during the entire observation period in all tillage options.

Keywords: weeds, herbicides, spring wheat, minimal tillage, crop rotation.

Введение. На протяжении всей истории земледелия сорные растения всегда являлись конкурентами для выращиваемых культур в борьбе за питательные вещества почвы и фотосинтез. В частности, освоение почвозащитной системы земледелия за довольно короткий срок вызывало изменение соотношения сорных растений в агрофитоценозе. Например, поверхностные обработки почвы на юге Западной Сибири привели к значительному росту засоренности посевов мятликовыми сорняками в сравнении с другими группами сорных растений [1], Число многолетних сорных растений сильнее нарастало по безотвальным обработкам, особенно по минимальным, а малолетних - по вспашке [2], С.Н. Саленков [3], проанализировав системы обработки почвы в разных климатических зонах России, пришел к выводу, что минимальные обработки почвы могут увеличить засоренность полей за ротацию севооборота в 4,0-7,0 раза при отсутствии мер химической борьбы, при этом особенно заметно нарастает количество многолетних сорных растений. Известно, что решение данной проблемы достигается за счет химических средств борьбы с сорняками.

В мире постоянно идет разработка новых эфффективных средств борьбы с вредными организмами, но несмотря на это, постоянно появляются сообщения из разных стран об увеличении количества сорных растений на сельскохозяйственных угодьях. Сформировалось научное мнение о том, что уничтожить полностью все сорные растения на полях невозможно. Ка- 
ковы причины высокой численности вредных объектов на полях?

Разные авторы называют неодинаковые причины усиления засоренности посевов сельскохозяйственных культур. Есть много исследований о появлении устойчивости сорных растений к гербицидам [4-7]. Для преодоления устойчивости фирмы-производители пестицидов вынуждены постоянно совершенствовать свой арсенал гербицидов [8].

Есть также много научных сообщений об изменении климата на планете. Климат влияет на изменение видового состава сорных растений и нарастание их количества. В последние несколько десятилетий температура воздуха в регионах, занимающихся выращиванием зерновых, во всем мире повышается, средние тренды составляли примерно $0,3{ }^{\circ} \mathrm{C}$ за десятилетие. Это связывают с увеличением выбросов углекислого газа в атмосфреру [9]. Глобальное потепление является причиной изменения урожайности сельскохозяйственных культур [10]. Такие же сообщения о потеплении есть и из регионов России, в том числе и Западной Сибири. По данным Федеральной службы по гидрометеорологии, в Западной Сибири за последние годы произошло потепление на $1,33^{\circ} \mathrm{C}$. Это, возможно, привело к усилению засоренности зерновых культур степными растениями [11]. В настоящее время во многих странах производители сельскохозяйственной продукции переходят на почвозащитное земледелие. Это связано с сильной изношенностью почвы и стремлением к экологическому равновесию. Такое земледелие предполагает отказ от применения вспашки, уменьшение механической нагрузки на почву. Но это также приводит к усилению засоренности полей. Есть сообщения о том, что эфффективность борьбы с сорняками при органической системе земледелия снижается в сравнении с обычной [12], В России также наблюдается тенденция к уменьшению нагрузки на почву, для чего в прогрессивных хозяйствах применяют безотвальные обработки почвы или минимальные плоскорезные. Появились интересные рекомендации по применению систем земледелия без обработки почвы, так называемой No-Till. Однако есть много исследований о том, что природо- охранное сельское хозяйство изменяет динамику и видовой состав сообщества сорных растений и требует дополнительных методов борьбы с сорняками $[13,14]$. Многие авторы сообщают о нарастании численности сорных растений, особенно многолетних, при минимизации обработки почвы [15-18].

Цель исследований. Анализ факторов, влияющих на изменение численности и видового состава сорных растений в посевах колосовых культур в зернопаровом севообороте при разных уровнях химизации и минимизации зяблевой обработки черноземных почв в лесостепи Западной Сибири.

Задачи исследований: анализ состояния вопроса; изучение особенностей изменения численности и видового состава сорных растений в посевах колосовых культур в зернопаровом севообороте при разных уровнях химизации и минимизации зяблевой обработки черноземных почв; поиск способов эфффективного сдерживания численности сорных растений в посевах яровой пшеницы при разных приемах минимизации обработки почвы.

Объекты и методы исследований. Исследования проводили в многофракторном полевом стационарном опыте «СибНИИЗиХ» СФНЦА РАН в лесостепи Западной Сибири на протяжении 1986-2019 гг. С 1981 по 1990 г. культуры возделывали в 5-польном севообороте: парозимая рожь-пшеница-овес (ячмень)-пшеница; в 1991-2006 гг. его реорганизовали в 4-польный: пар-озимая рожь-пшеница-пшеница; с 2007 г. озимую рожь заменили пшеницей: парпшеница-пшеница-пшеница. За период исследований прошло 8 ротаций севооборота. В зернопаровом севообороте исследовали разные варианты зяблевой обработки почвы: 1. Вспашка, на 20-22 см (в пару на 25-27 см). 2. Безотвальная обработка стойками СибИМЭ на 2022 см (в пару на 25-27 см). 3. Минимальная обработка культиватором «Степняк» на глубину 10-12 см. 4. Без зяблевой обработки («нулевая обработка»).

Почва опытного поля представлена черноземом выщелоченным. Мощность гумусового горизонта составляет $39 \mathrm{~cm}$, глубина пахотного 
слоя 27 см. Содержание гумуса в верхнем слое почвы 6,0\%.

Площади под делянками по основной обработке почвы составляли $1300 \mathrm{~m}^{2}$ (13×100 м). Опыт заложен в 4 повторениях, расположение вариантов систематическое. Поперек основных обработок методом расщепленных делянок накладывались разные варианты применения химических средств интенсификации: экстенсивный фон (без средств химизации); интенсивный фон (фосфорные удобрения в пару в дозе Р120 на ротацию севооборота, N60 под вторую и N90 под третью культуры после пара, гербициды, фунгициды, инсектициды). В паровом поле на интенсивном фоне для снижения засоренности одну механическую обработку заменяли гербицидами (Раундап или Торнадо). Учет засоренности посевов во всех вариантах опыта осуществляли методом маршрутных обследований с подробным описанием видового состава на учетных площадках в фазу всходов, кущения и перед уборкой. Учет урожая с учетных делянок проводили методом сплошного комбайнирования комбайном «Сампо».

Развитие сорняков и болезней в значительной степени зависит от наличия влаги и тепла, поэтому важно учитывать, какие погодные условия были во время исследований. Климат Западной Сибири очень изменчивый. За 33 года исследований наблюдали повышенное увлажнение в 5 годах, умеренное увлажнение в 10 годах, дефицитное увлажнение в 14, а 4 года была засуха. За год в лесостепи Западной Сибири выпадает в среднем 400-540 мм атмоссрерных осадков, из них в июне - 55-65 мм. Коэффициент увлажнения на территории Западной Сибири составляет 1,0-1,36. Средние многолетние суммы температур выше $5-10{ }^{\circ} \mathrm{C}$ составляют $1880-1940{ }^{\circ} \mathrm{C}$, выше $10-12{ }^{\circ} \mathrm{C}-$ 1620-1680.

Результаты исследований и их обсуждение. Набор сорных растений на опытном поле был типичным для лесостепной зоны Западной Сибири. Наиболее распространены на поле около 30 видов растений. В первые годы существования опытного поля состав сорной расти- тельности был представлен следующими видами: просо сорнополевое (Echinochloa crusgalli (L.) Beanw., Panicum miliaceum L.), щетинники сизый и зеленый (Setaria viridis L., S.pumila (Po: ret) Schultes), овсюг (Avena fatua), щирица запрокинутая (Amaranthus retroflexus L.), пикульник двунадрезной (Galeopsis bifida Boenn.), гречишка вьюнковая (Fallopia convolvulus (L.) A.Love), гречиха татарская (Fagopirum tataricum (L.) Gaertn.), разные виды капустовых (Brassica campestris L., Neslia paniculata (L.) Desv., Raphanus raphanistrum L.). Многолетние сорные растения на поле встречались редко: Sonchus arvensis L., Cirsium setosum (Willd.) Bess., вьюнок полевой (Convolvulus arvensis L.). Большую часть сорняков составляли злаковые растения (преимущественно просовидные), очень часто встречался овсюг.

На экстенсивном фоне, где не применялись средства химизации, численность сорных растений сдерживалась механическими обработками. Осенью они уничтожались при зяблевой обработке, весной - культивациями и боронованием. В паровом поле применялись 3 культивации в течение лета. Однако исследования показали, что этого недостаточно для поддержания благоприятной фитосанитарной ситуации. Во втором севообороте произошли существенные изменения в видовом и численном составе сорной растительности. Исследования показали, что без средств химической защиты растений в севообороте идет постепенное накопление сорной растительности (рис. 1). Средний процент сорняков на поле в 1986-1990 годах составлял 14,9 \%, в 1991-1995 годах средняя засоренность уже увеличилась до 19,3\%, а в 2001-2005 годах до 25,8 \%. В 2006-2011 годах доля сорных растений достигла уже $40 \%$ на контроле. На рисунке видно постепенное нарастание доли сорных растений в агроценозе. После этого дополнительно стали применять в паровом поле один раз за вегетацию гербицид Глифосат. Это позволило немного снизить численность сорных растений на контроле, на графике видно постепенное уменьшение доли сорных растений в течение последних 8 лет. 


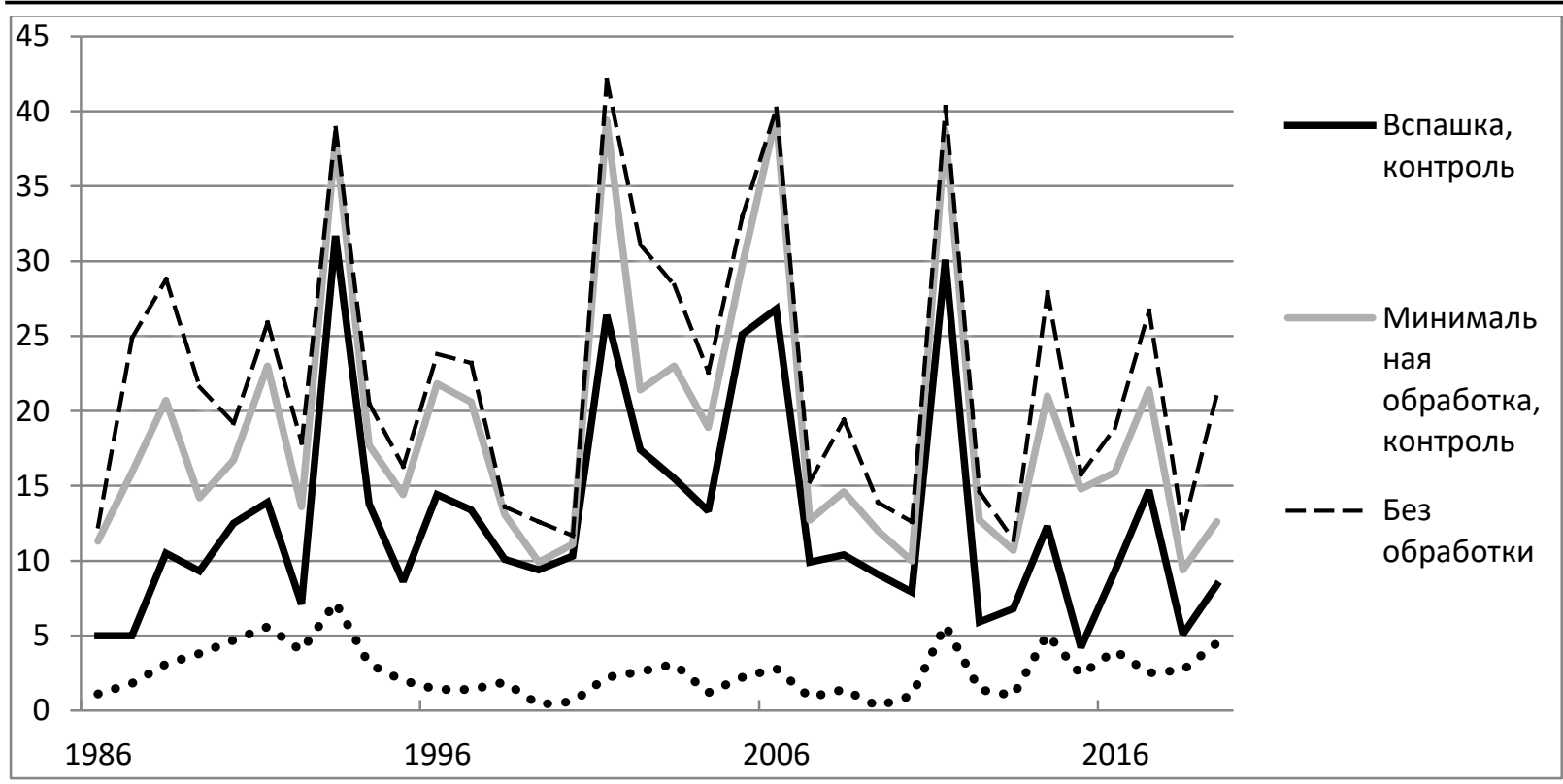

Puс. 1. Доля сорных растений в посевах яровой пшеницы перед уборкой при минимизащии зяблевой обработки, 1986-2019 г2.

При использовании безотвальных приемов обработки почвы накопление сорняков происходило значительно интенсивнее, чем в варианте «вспашка». Например, в 2001-2005 годах в варианте «вспашка» доля сорных растений в среднем составила $19,5 \%$, а в варианте «безотвальная обработка» $-25,7 \%$. Без зяблевой обработки почвы доля сорных растений в биоценозе за эти годы достигла 31,4 \%. Минимальная обработка почвы без применения гербицидов за 10 лет привела к увеличению засоренности посевов в 1,4-1,8 раза. Отказ от осенней обработки почвы вызвал увеличение числа сорных растений в 2,3 раза в сравнении со вспашкой.

По разным годам исследований отмечалось существенное варьирование числа сорных растений. Эти регулярные изменения объясняются в основном количеством осадков за вегетационный период. Зависимость сорных растений в посевах пшеницы от индекса увлажнения года показана на рисунке 2. В годы с нормальным увлажнением доля сорняков на контроле составила $17,1 \%$. В годы с десицитом осадков (коэффицциент увлажнения $<0,8)$ засоренность полей составляла 8,9 \%. Во влажные годы (коэфффициент увлажнения >1,2) она достигала $28,0 \%$.

За все время проведения экспериментов нарастание численности сорных растений происходило преимущественно за счет однодольных видов. Доля однолетних двудольных сорных растений во всех вариантах не превышала 2,0$3,0 \%$. Многолетние сорные растения в варианте «вспашка» практически не встречались. Они появлялись при минимальных способах основной обработки почвы, особенно в варианте без зяблевой обработки («нулевая»).

Через 20 лет существования опыта мы стали отмечать существенное изменение видового состава сорных растений. Это связано не только с почвозащитными обработками, но и, возможно, с изменением климата в Западной Сибири. По данным Федеральной службы по гидрометеорологии, в Западной Сибири за последние годы произошло потепление на $1,33^{\circ} \mathrm{C}$. Потепление сопровождалось десрицитом атмоссрерных осадков, что обеспечивало преимущество на поле степным видам сорных растений. Просовидные сорные растения ранее были распространены преимущественно в степной зоне, а теперь они стали наиболее агрессивной группой в лесостепи Западной Сибири. Количество этих сорных растений на контроле неуклонно нарастает и достигает на последней культуре в севообороте 66,0-75,0 \%. Овсюг оказался менее конкурентоспособен в новых условиях, численность его постепенно снизилась до единичных значений. 


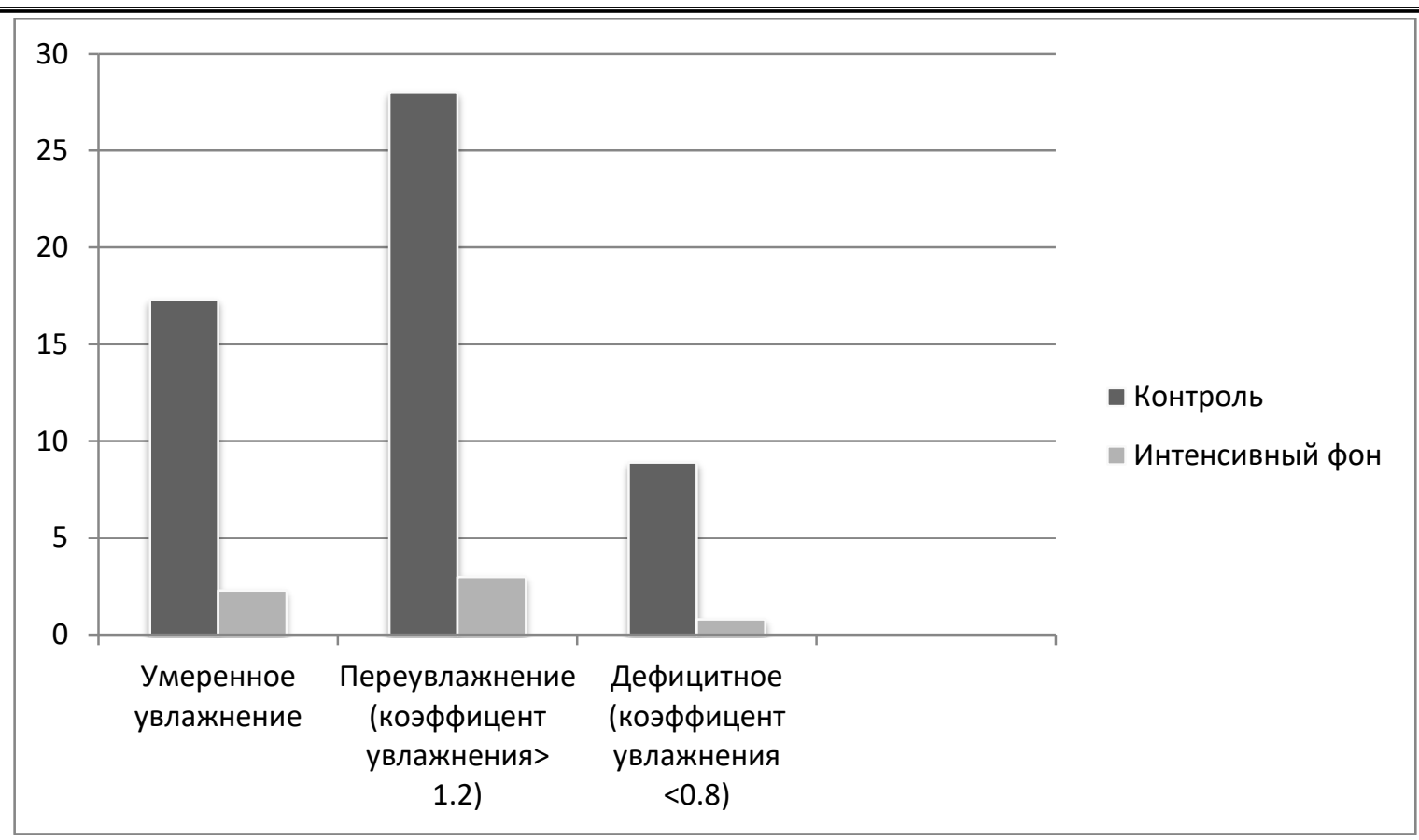

Puс. 2. Доля сорных растений в посевах яровой пшеницы в зависимости от погодных условий года, в среднем за 1996-2019 ге.

В последние годы мы отметили также нарастание численности степных видов сорняков, таких как дымянка лекарственная (Fumaria officinalis (L)), щирица жминдовидная (Amaranthus blitoides S.Wats.), липучка щетинистая (Lappula squarrosa (Retz.) Dum.)). Увеличилась численность устойчивых к гербицидам сорных растений, таких как гречиха татарская, паслен черный (Solanum nigrum L.), горец развесистый (Persicaria lapathifolia (L.) S.F.Gray).

На интенсивном фоне химические препараты для борьбы с сорными растениями применяли один раз за вегетацию, обычно в фазу кущения яровой пшеницы. Применяли смесь препаратов против всех видов сорняков одновременно. Важно было дождаться, когда ряды посевов пшеницы начнут смыкаться, так как слишком ранняя обработка могла стать причиной повторного прорастания сорных растений. Численность сорных растений во все годы исследований на интенсивном фоне не превышала порога вредоносности. До 1994 года доля сорных растений составляла в среднем 3,9 \%. В посевах пшеницы сохранялись преимущественно сорняки, устойчивые к гербицидам.

С 1994 года в России появились новые препараты для защиты растений производства ведущих мировых фирм. На интенсивном фоне начали применять новые эффективные гербициды. Мы использовали на посевах препараты производства фирмы «Bayer», «Du Pont», «Doctor Farmer». В паровом поле один раз за вегетацию применяли Глифосат фирмы «Avgust». Hoвые препараты подавляли успешно даже устойчивые сорные растения. Доля сорных растений в посевах на фоне химической защиты растений была сведена к минимуму и стала составлять в среднем $1,4 \%$.

Важно отметить, что видовой состав сорной растительности был неодинаковым при разных способах обработки почвы. В варианте «нулевая обработка» мы наблюдали частую встречаемость многолетних сорных растений, таких как вьюнок полевой, осоты, одуванчик, Sonchus arvensis L., Cirsium setosum (Willd.) Bess., а также фиалка полевая, липучки (Lappula squarrosa (Retz.) Dum.) и Galium aparine L. Высокую встречаемость многолетних сорных растений наблюдали и в вариантах минимальной обработки почвы. В вариантах с минимальной и «нулевой» обработками большая часть семян сорных растений остается на поверхности почвы и очень быстро прорастает. В варианте «вспашка» многие семена сорных растений попадают в нижние горизонты почвы и погибают. В варианте «вспашка» чаще встречались лебеда и разные 
виды дикой капусты, так как их семена требовательны к низкой плотности почвы. Многолетние сорные растения в варианте «вспашка» практически не встречались.

Эти результаты оказали существенное влияние на урожайность яровой пшеницы. На интенсивном фоне во всех вариантах обработки почвы урожайность была высокой в среднем за все годы исследований. По вспашке собрали в среднем 3,33 т/га. В вариантах с минимальной обработкой урожайность была 3,13 т/га, без осенней обработки почвы - 3,01 т/га. На фроне без средств химизации в те же годы высокая численность сорных растений и отсутствие удобрений вызвали значительное снижение урожая. Урожайность по вспашке без пестицидов составляла в среднем 1,58 т/га. В варианте с минимальной обработкой на контроле получили 1,39, а по «нулевой» обработке почвы - 1,24 т/га.

Выводы. В зернопаровом севообороте на черноземах выщелоченных без применения гербицидов отмечено нарастание численности сорных растений. В 1986 году средняя доля сорняков от агрофитоценоза на контроле (без средств химизации) составляла $14,9 \%$, а при прохождении семи ротаций зернопаровых севооборотов (2016 г.) она увеличивалась до $25,8 \%$. Рост доли сорных растений в посевах идет быстрее в 1,5-2,3 раза в вариантах с минимальными обработками в сравнении со вспашкой. В варианте без зяблевой обработки («нулевая») сорные растения составляли в среднем $31,4 \%$, а в варианте по вспашке - 19,5\%.

Применение минимальных приемов обработки почвы, особенно полное отсутствие зяблевой обработки, вызывало изменение видового состава сорных растений. «Нулевая» зяблевая обработка приводила к значительному увеличению численности сорных растений в посевах зерновых, а также к большему разнообразию их видового состава. Без зяблевой обработки почвы значительно размножались многолетние сорняки, а также такие сорные растения, как фиалка полевая, липучки (Lappula squarrosa (Retz.) Dum. и Galium aparine L.). В вариантах с минимальной обработкой почвы также наблюдали увеличение численности многолетних растений. Возможно, на видовой состав сорных растений оказало влияние изменение климата в Западной Сибири, что привело к увеличению численности степных видов, таких как Fumaria officinalis (L.), Amaranthus blitoides S.Wats., Lappula squarrosa (Retz.) Dum. Такое предположение обусловлено цикличностью изменения климата, в частности в Западной Сибири.

Грамотное применение химических препаратов позволяет сдерживать численность сорных растений в зернопаровом севообороте на уровне ниже порога вредоносности. Для обеспечения чистоты посевов яровой пшеницы за вегетацию в Западной Сибири достаточно однократного применения баковой смеси эфффективных компонентов, например, таких как Феноксапроп-П-этил + 2,4-Д кислота + дикамба кислота. Главное условие высокой эфффективности препаратов - применение их в оптимальные сроки. В нашем эксперименте на фоне защиты растений численность сорняков в течение 33 лет оставалась ниже порога вредоносности во всех вариантах опыта. Численность сорных растений на интенсивном фоне была очень низкой даже по минимальным и «нулевым» приемам обработки почвы. Это позволяло получить относительно высокую урожайность яровой пшеницы независимо от изучаемых систем зяблевой обработки почвы (3,01-3,33 т/га).

\section{Литература}

1. Доронин В.Г., Ледовский Е.Н., Дмитриев В.И. Эфффективность защиты зерновых культур на юге Западной Сибири // Защита и карантин растений. 2012. № 10. С. 22-23.

2. Кислов А.В., Бакиров Ф.Г., Федюнин С.А. Ресурсосберегающие технологии обработки почвы под зерновые культуры // Земледелие. 2004. № 4. С. 24-25.

3. Саленков С.Н. Современные энергосберегающие технологии // Земледелие. 2001. № 5. C. 8-9.

4. Beckie H.J., Tardif F.J. 2012. Herbicide cross resistance in weeds. Crop Protection 35: 1528. CrossRefGoogle Scholar.

5. Adamczewski K., Kierzek R., Matysiak K. 2016. Multiple resistance to acetolactate synthase (ALS)- and acetyl-coenzyme A carboxylase (ACCase)-inhibiting herbicides in blackgrass (Alopecurus myosuroides Huds.) populations from Poland. Journal of Plant Protection Research: 56 (4): 402-410 p. 
6. Busi R., Vila-Aiub M.M., Beckie H.J., Gaines T.A., Goggin D.E., Kaundun S.S., Lacoste M., Neve P., Nissen S.J., Norsworthy J.K., et al. 2013. Herbicide-resistant weeds: from research and knowledge to future needs. Evol Appl 6: 1219-1221.

7. Palma-Bautista C., Tahmasebi B.K., Fernández-Moreno P.T., Rojano-Delgado A.M., Cruz R.A., Prado R. 2018. First Case of Conyza canadensis from Hungary with Multiple Resistance to Glyphosate and Flazasulfuron. Agronomy 8(8), 157. DOl: 10.3390/agronomy8080157.

8. Kraehmer H., Laber B., Rosinger C., Schulz A. 2014. Herbicides as weed control agents: state of the art: I. Weed control research and safener technology: the path to modern agriculture. Plant Physiol 166: 1119-1131.

9. Peters G.P., Marland G., Le Quéré C., Boden T., Canadell J.G., Raupach M.R. 2011. Rapid growth in CO2 emissions after the 2008-2009 global financial crisis. Nature Climate Change 2: 2-4 C.

10. Lobell D.B., Gourdji S.M. 2012. The Influence of Climate Change on Global Crop Productivity. Plant Physiology: DOI: 10.1104/pp.112.208298.

11. Синещеков В.Е., Васильева Н.В. Засоренность зерновых агроценозов при минимизации основной обработки почвы в лесостепи Приобья // Вестник НГАУ. 2017. № 4 (45). C. 32-40.

12. Feledyn-Szewczyk B. 2012. The effectiveness of weed regulation methods in spring wheat cultivated in Integrated, conventional and organic crop production systems. Journal of Plant Protection Research 52 (4): 486-493 p.

13. Pittelkow C.M., Linquist B.A., Lundy M.E., Liang X., van Groenigen K.J., Lee J.d van Gestel, N.c Six J.d, Venterea R.T. e,f, van Kessel C. 2015. Weed dynamics and conservation agriculture principles: A review Volume 183, P. 56-68.

14. Власенко Н.Г., Коротких Н.А., Бокина И.Г. К вопросу о формировании фритосанитарной ситуации в посевах в системе No-Till. Новосибирск, 2013. 122 с.

15. Рзаева В.В. Системы основной обработки почвы в земледелии Северного Зауралья: автореф. дис. ... д-ра с.-х. наук. Тюмень. 2014. 32 c.
16. Синещеков В.E., Васильева Н.В. Динамика засоренности зерновых агроценозов // Вестник Российской академии сельскохозяйственных наук. 2010. № 4. С. 21-23.

17. Ленточкин А.М., Широбоков П.Е., Ленточкина Л.А. Засоренность посевов яровой пшеницы в зависимости от приемов зяблевой обработки почвы // Защита и карантин растений. 2015. № 12. С. 29-31.

18. Немченко В.В., Рыбина Л.Д., Копылов А.Н. [и др.]. Борьба с засоренностью посевов при ресурсосберегающих технологиях в земледелии Зауралья // Земледелие. 2008. № 5. C. 38-40.

\section{Literatura}

1. Doronin V.G., Ledovskij E.N., Dmitriev V.I. Jeffektivnost' zashhity zer-novyh kul'tur na juge Zapadnoj Sibiri // Zashhita i karantin rastenij. 2012. № 10. S. 22-23.

2. Kislov A.V., Bakirov F.G., Fedjunin S.A. Resursosberegajushhie tehnologii obrabotki pochvy pod zernovye kul'tury // Zemledelie. 2004. № 4. S. 24-25.

3. Salenkov S.N. Sovremennye jenergosberegajushhie tehnologii // Zemledelie. 2001. № 5. S. 8-9.

4. Beckie H.J., Tardif F.J. 2012. Herbicide cross resistance in weeds. Crop Protec-tion 35: 1528. CrossRefGoogle Scholar.

5. Adamczewski K., Kierzek R., Matysiak K. 2016. Multiple resistance to aceto-lactate synthase (ALS)- and acetyl-coenzyme A carboxylase (ACCase)-inhibiting herbicides in blackgrass (Alopecurus myosuroides Huds.) populations from Poland. Journal of Plant Protection Research: 56 (4): 402-410 p.

6. Busi R., Vila-Aiub M.M., Beckie H.J., Gaines T.A., Goggin D.E., Kaundun S.S., Lacoste M., Neve P., Nissen S.J., Norsworthy J.K., et al. 2013. Herbicide-resistant weeds: from research and knowledge to future needs. Evol Appl 6: 1219-1221.

7. Palma-Bautista C., Tahmasebi B.K., Fernández-Moreno P.T., Rojano-Delgado A.M., Cruz R.A., Prado R. 2018. First Case of Conyza canadensis from Hungary with Multiple Resistance to Glyphosate and Flazasulfuron. 
Agronomy 8(8), 157. DOI: 10.3390/ agronomy8080157.

8. Kraehmer H., Laber B., Rosinger C., Schulz A. 2014. Herbicides as weed control agents: state of the art: I. Weed control research and safener technology: the path to modern agriculture. Plant Physiol 166: 1119-1131.

9. Peters G.P., Marland G., Le Quéré C., Boden T., Canadell J.G., Raupach M.R. 2011. Rapid growth in CO2 emissions after the 2008-2009 global financial crisis. Nature Climate Change 2: 2-4 C.

10. Lobell D.B., Gourdji S.M. 2012. The Influence of Climate Change on Global Crop Productivity. Plant Physiology: DOI. URL: https://doi.org/10.1104/pp.112.208298.

11. Sineshhekov V.E., Vasil'eva N.V. Zasorennost' zernovyh agrocenozov pri minimizacii osnovnoj obrabotki pochvy v lesostepi Priob'ja // Vestnik NGAU. 2017. № 4 (45). S. 32-40.

12. Feledyn-Szewczyk B. 2012. The effectiveness of weed regulation methods in spring wheat cultivated in Integrated, conventional and organic crop production systems. Journal of Plant Protection Research 52 (4): 486-493 p.

13. Pittelkow C.M., Linquist B.A., Lundy M.E., Liang X., van Groenigen K.J., Lee J.d van
Gestel, N.c Six J.d, Venterea R.T. e,f, van Kessel C. 2015. Weed dynamics and conservation agriculture principles: $A$ review Volume 183, P. 56-68.

14. Vlasenko N.G., Korotkih N.A., Bokina I.G. K voprosu o formirovanii fitosanitarnoj situacii $v$ posevah v sisteme No-Till. Novosibirsk, 2013. $122 \mathrm{~s}$.

15. Rzaeva V.V. Sistemy osnovnoj obrabotki pochvy $v$ zemledelii Severnogo Zaural'ja: avtoref. dis. ... d-ra s.-h. nauk. Tjumen'. 2014. $32 \mathrm{~s}$.

16. Sineshhekov V.E., Vasil'eva N.V. Dinamika zasorennosti zernovyh agrocenozov // Vestnik Rossijskoj akademii sel'skohozjajstvennyh nauk. 2010. № 4. S. 21-23.

17. Lentochkin A.M., Shirobokov P.E., Lentochkina L.A. Zasorennost' posevov jarovoj pshenicy v zavisimosti ot priemov zjablevoj obrabotki pochvy // Zashhita i karantin rastenij. 2015. № 12. S. 29-31.

18. Nemchenko V.V., Rybina L.D., Kopylov A.N. [l dr.]. Bor'ba s zasorenno-st'ju posevov pri resursosberegajushhih tehnologijah $\mathrm{V}$ zemledelii Zaural'ja // Zemledelie. 2008. № 5. S. $38-40$. 